\title{
Haematological Traits of Nigerian Indigenous Pig and Its Hybrid (50\% Large White $\times 50$ NIP) at Post Weaning Ages
}

\author{
0. O. Oluwole ${ }^{*}$, G. O. Omitogun ${ }^{2}$ \\ ${ }^{1}$ Institute of Agricultural Research and Training, Obafemi Awolowo University, Ibadan, Nigeria \\ ${ }^{2}$ Animal Science Department, Faculty of Agriculture, Obafemi Awolowo University, lle-Ife, Nigeria \\ Email: "oluwafunmike@yahoo.co.uk
}

Received 2 November 2015; accepted 26 January 2016; published 29 January 2016

Copyright (C) 2016 by authors and Scientific Research Publishing Inc.

This work is licensed under the Creative Commons Attribution International License (CC BY).

http://creativecommons.org/licenses/by/4.0/

\section{(c) () Open Access}

\section{Abstract}

Pigs play a major role in socioeconomic life of the people; it serves as a source of income for rural population and fulfill important role in culture and food security. Fifty-one weaners were randomly selected at 9, 17 and 25 weeks of age for analysis. Blood from the jugular vein of the weaners was taken to the laboratory for analysis. The leaukocyte parameters used for this study were White blood cell count (WBC), Lymphocyte (LYM) count, Neutrophil (NEU) count, Eosinophil (EOS) and Monocyte (MON) count) and Platelet (PLT) count. Data collected on these leaukocyte parameters were subjected to Analysis of Variance (ANOVA) while the means were separated using Duncan's Multiple Range Test. The results showed that at 9 weeks of age, compared with the female hybrid, the male hybrid had higher PCV, NEU and EOS $(33.12 \% \pm 2.73 \%, 31.00 \% \pm 3.37 \%$ and $0.38 \%$ $\pm 0.18 \%$ respectively) values, while the female NIP had higher WBC, LYM and MON $(24.55 \pm 1.09 \times$ $10^{3} / \mu \mathrm{l}, 56.00 \% \pm 3.24 \%$ and $0.50 \% \pm 0.50 \%$ ) values respectively. At 17 weeks of age, the male hybrid had higher WBC and NEU $\left(32.18 \pm 1.92 \times 10^{3} / \mu \mathrm{l}\right.$ and $\left.32.38 \% \pm 3.56 \%\right)$ values while the female had higher PCV, LYM, EOS and MON $(42.50 \% \pm 1.50 \%, 63.00 \% \pm 5.0 \%, 2.50 \% \pm 2.50 \%$ and $4.50 \%$ $\pm 1.50 \%$ ) values. At 25 weeks of age, the female hybrid had higher values in all the parameters with the exception of NEU and MON where male had higher values. These ages can be used as criteria for selection for immunocompetence in pigs.

\section{Keywords}

Nigerian Indigenous Pigs, Hybrid, Leukocyte Traits, Post Weaning Age

\footnotetext{
${ }^{*}$ Corresponding author.
}

How to cite this paper: Oluwole, O.O. and Omitogun, G.O. (2016) Haematological Traits of Nigerian Indigenous Pig and Its Hybrid (50\% Large White $\times 50$ NIP) at Post Weaning Ages. American Journal of Molecular Biology, 6, 45-52. 


\section{Introduction}

The pig population in Nigeria is about 7 million in 1997, where most of which are raised on smallholder farms [1]. They are concentrated mainly in the Middle and Southern States of the country due to religious, cultural and local taboo. One of the important indicators of health and disease in animals is the haematological profile. It is very important in diagnosis, treatment or prognosis of many diseases [2]. Determination of the haematological profiles reflects the physiological responsiveness of the animals to its internal and external environments [3]. Radostits et al. (1994) [4] reported that the intensification of animal agriculture had created complex animal health and production of more problems for which there were no simple and reliable therapeutic and preventive procedures. These conditions adversely affect the health or welfare of the animals and impair their homeostatic mechanisms resulting in the body dysfunction which may be fatal [5].

The blood consisting of blood cells and plasma are responsible for transportation, regulation, protection and homeostatic functions in the animal body [6]. Anaemia has been described for many diseases and management problems and physiological state such as age in pigs. Determination of the Packed Cell Volume (PCV), erythrocyte count (RBC) and haemoglobin (Hb) can give indications of the level of anaemia in the animal. Haematological parameters of pig have been widely studied and have been reported to vary depending on sex, age, geographical location and experimental procedures [4] [7]-[9]. This study is to provide the empirical evidence needed for the conservation and utilization of NIP and its crossbred in swine improvement programme. The specific objective is to evaluate growth and leukocyte traits of NIP and its hybrid at post-weaning ages of 9,17 and 25 weeks.

\section{Materials and Methods}

Fifty-one weaners, from breeding plan in Table 1, were randomly selected at 9, 17 and 25 weeks of age for

Table 1. Effect of genotype and age on leucocyte traits.

\begin{tabular}{|c|c|c|c|}
\hline \multirow[t]{2}{*}{ Age } & \multirow[t]{2}{*}{ Traits } & \multicolumn{2}{|c|}{ Breed } \\
\hline & & Hybrid & NIP \\
\hline \multirow[t]{4}{*}{9 weeks } & ${ }^{*}$ PCV (\%) & $32.30 \pm 2.45^{b}$ & $40.62 \pm 0.65^{\mathrm{a}}$ \\
\hline & ${ }^{*}$ WBC $\left(\times 10^{3} / \mu \mathrm{l}\right)$ & $25.64 \pm 2.63^{\mathrm{a}}$ & $22.78 \pm 1.09^{\mathrm{b}}$ \\
\hline & ${ }^{*}$ NEU (\%) & $27.30 \pm 3.63^{b}$ & $41.38 \pm 3.01^{\mathrm{a}}$ \\
\hline & "LYM (\%) & $72.30 \pm 3.65^{\mathrm{a}}$ & $57.12 \pm 2.87^{b}$ \\
\hline EOS (\%) & & $0.30 \pm 0.15$ & $1.00 \pm 0.33$ \\
\hline MON (\%) & & $0.10 \pm 0.10$ & $0.50 \pm 0.33$ \\
\hline \multirow[t]{4}{*}{17 weeks } & PCV (\%) & $41.90 \pm 0.43$ & $41.62 \pm 1.34$ \\
\hline & WBC $\left(\times 10^{3} / \mu \mathrm{l}\right)$ & $32.96 \pm 1.76$ & $32.96 \pm 1.72$ \\
\hline & ${ }^{*}$ NEU (\%) & $31.90 \pm 2.96^{b}$ & $41.88 \pm 3.68^{\mathrm{a}}$ \\
\hline & ${ }^{*}$ LYM (\%) & $63.10 \pm 2.95^{a}$ & $53.12 \pm 3.97^{b}$ \\
\hline EOS (\%) & & $1.90 \pm 0.90$ & $2.75 \pm 0.90$ \\
\hline MON (\%) & & $3.10 \pm 0.6$ & $2.25 \pm 0.96$ \\
\hline \multirow[t]{2}{*}{25 weeks } & ${ }^{*}$ PCV (\%) & $38.86 \pm 1.26^{b}$ & $43.88 \pm 1.26^{\mathrm{a}}$ \\
\hline & WBC $\left(\times 10^{3} / \mu \mathrm{l}\right)$ & $35.54 \pm 1.87$ & $37.70 \pm 1.87$ \\
\hline NEU (\%) & & $32.43 \pm 2.84$ & $32.88 \pm 2.61$ \\
\hline LYM (\%) & & $61.00 \pm 2.59$ & $60.38 \pm 2.86$ \\
\hline EOS (\%) & & $2.00 \pm 0.5$ & $83.00 \pm 0.95$ \\
\hline MON (\%) & & $4.86 \pm 0.4$ & $64.25 \pm 0.50$ \\
\hline
\end{tabular}

${ }^{\mathrm{a}, \mathrm{b}}$ Mean values for each trait along row with different superscript letters, are different. ${ }^{*}$ Level of significance $(\mathrm{P}<$ 0.05). PCV—Packed cell volume, WBC—White blood cell, NEU—Neutrophil, LYM—Lymphocyte, EOS— Eosinophil, MON—Monocytes, NIP—Nigerian Indigenous Pig. 
haematological analysis. Blood from the jugular vein of these pigs were collected into anti-coagulant bottles and taken to the laboratory for analysis. The blood parameters taken were packed cell volume (PCV\%) and leukocyte traits (white blood cell count (WBC), neutrophilic count (NEU\%), eosinophil percentage (EOS\%), lymphocyte percentage (LYM\%), and monocytes percentage (MON\%)). The PCV was determined using the microhaematocrit method while leucocyte counts were determined using the improved Neubauer counting chamber [8].

\subsection{Packed Cell Volume (PCV)}

$75 \times 16 \mathrm{~mm}$ capillary tubes were filled with blood and centrifuged at $3000 \mathrm{rpm}$ for 5 minutes. The haematocritvalues were determined with the aid of a microhaematocrit reader.

\subsection{White Blood Cell Counts}

Blood was well mixed on a roller mixer and 1:20 dilution of blood was made by adding $20 \mu \mathrm{l}(0.02 \mathrm{ml})$ of pigs blood to $0.38 \mathrm{ml}$ of diluting fluid (2\% glacial acetic acid in distilled water (Turk's solution) coloured pale violet with $1 \%$ gentian violet) in a $75 \times 10 \mathrm{~mm}$ tube. The suspension was well mixed and allowed to stand for 1 minute. The cells were counted in the four corner square millimeters of the charged chamber (Improved Neubauer counting chamber) under $10 \times$ magnification of a microscope.

\subsection{Statistical Analysis}

Haematological data recorded were analyzed by using Analysis of variance (ANOVA) and means were separated by Duncan Multiple Range Test (DMRT).

\section{Results}

The means of leukocyte traits of hybrid at 9,17 and 25 weeks respectively are as follows; PCV $(32.30 \% \pm$ $2.45 \%, 41.90 \% \pm 0.43 \%, 38.86 \% \pm 1.26 \%) ; \mathrm{WBC}\left(25.64 \pm 2.63\left(\times 10^{3} / \mu \mathrm{l}\right), 32.96 \pm 1.76\left(\times 10^{3} / \mu \mathrm{l}\right), 35.54 \pm 1.87\right.$ $\left.\left(\times 10^{3} / \mu \mathrm{l}\right)\right)$; NEU $(27.30 \% \pm 3.63 \%, 31.90 \% \pm 2.96 \%, 32.43 \% \pm 2.84 \%) ;$ LYM $(72.30 \% \pm 3.65 \%, 63.10 \% \pm$ $2.95 \%, 61.00 \% \pm 2.59 \%)$; EOS $(0.30 \% \pm 0.15 \%, 1.90 \% \pm 0.90 \%, 2.00 \% \pm 0.58 \%)$ and MONO $(0.10 \% \pm 0.10 \%$, $3.10 \% \pm 0.6 \%, 4.86 \% \pm 0.46 \%)$. The mean for NIP at 9,17 and 25 weeks respectively are as follows; PCV $(40.62 \% \pm 0.65 \%, 41.62 \% \pm 1.34 \%, 43.88 \% \pm 1.26 \%) ; \mathrm{WBC}\left(22.78 \pm 1.09\left(\times 10^{3} / \mu \mathrm{l}\right), 32.96 \pm 1.72\left(\times 10^{3} / \mu \mathrm{l}\right)\right.$, $\left.37.70 \pm 1.87\left(\times 10^{3} / \mu \mathrm{l}\right)\right) ; \mathrm{NEU}\left(41.38 \% \pm 3.01 \%, 41.88 \% \pm 3.68 \%, 32.88 \% \pm 2.61 \%^{\mathrm{a}}\right) ; \mathrm{LYM}(57.12 \% \pm 2.87 \%$, $53.12 \% \pm 3.97 \%, 60.38 \% \pm 2.86 \%)$; EOS $(1.00 \% \pm 0.33 \%, 2.75 \% \pm 0.90 \%, 3.00 \% \pm 0.95 \%)$ and MONO $(0.50 \%$ $\pm 0.33 \%, 2.25 \% \pm 0.96 \%, 4.25 \% \pm 0.50 \%)$.

The PCV was significantly different $(\mathrm{P}<0.05)$ between hybrid and NIP at 9 and 25 weeks of age while there was no significant difference $(P>0.05)$ at 17 weeks of age. The Leukocyte count, NEU and LYM, were significantly different $(\mathrm{P}<0.05)$ between hybrid and NIP at 9 and 17 weeks of age while there was no significant difference $(P>0.05)$ at 25 weeks of age. It was observed that the LYM values for hybrid were higher than that of NIP while the NEU value for NIP were higher than that of hybrid throughout the ages considered $(9,17$ and 25 weeks). This is presented graphically in Figure 1.

The effect of sex and age on leukocyte traits for the hybrid and NIP at 9, 17 and 25 weeks of age are presented in Table 2 and Table 3 respectively.

The PCV of female and male hybrid were significantly different $(\mathrm{P}<0.05)$ from each other at 9 weeks $(29.00 \%$ $\pm 4.00 \%$ and $33.12 \% \pm 2.73 \%)$ and 25 weeks $(42.00 \% \pm 0.00 \%$ and $38.33 \% \pm 1.38 \%)$ of age. Also at 9 and 25 weeks of age, the Leukocyte traits, WBC $\left(28.90 \pm 4.60\left(\times 10^{3} / \mu \mathrm{l}\right), 24.83 \pm 3.15\left(\times 10^{3} / \mu \mathrm{l}\right.\right.$ and $41.00 \pm 0.00$ $\left(\times 10^{3} / \mu \mathrm{l}\right)$ and $\left.34.63 \pm 1.94\left(\times 10^{3} / \mu \mathrm{l}\right)\right)$, NEU $(12.50 \% \pm 1.50 \%$ and $31.00 \% \pm 3.37 \%, 22.00 \% \pm 0.00 \%$ and $34.17 \%$ $\pm 2.66 \%)$ and LYM $(87.00 \% \pm 1.00 \%$ and $68.63 \% \pm 3.43 \%, 72.00 \% \pm 0.00 \%$ and $59.17 \% \pm 2.17 \%)$, were significantly different $(\mathrm{P}<0.05)$. The female and male hybrid MONO $(3.00 \% \pm 0.00 \%$ and $5.17 \% \pm 0.40 \%)$ and EOS $(3.00 \% \pm 0.00 \%$ and $4.83 \% \pm 0.65 \%)$ were significantly different $(\mathrm{P}<0.05)$ at 25 weeks of age.

The NEU and LYM of NIP females and males were significantly different throughout the ages except at 17 weeks of age where the LYM was not significantly different $(P>0.05)$. The WBC was also significantly different at 9 and 17 weeks while it was not significant at 25 weeks of age. This effect is presented graphically in Figures 2-4. The PCV and NEU values were higher in NIP males and females at 9 weeks but were comparable 


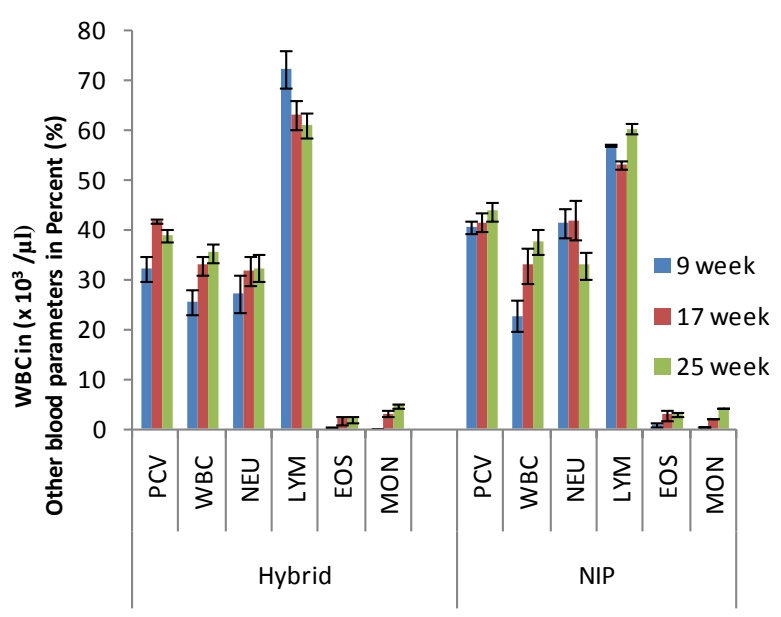

Figure 1. Effect of genotype on the haematological traits at 9, 17 and 25 weeks. PCV—Packed cell volume, WBC-White blood cell, NEU-Neutrophil, LYMLymphocyte, EOS—Eosinophil, MON-Monocytes, NIP-Nigerian Indigenous Pig.

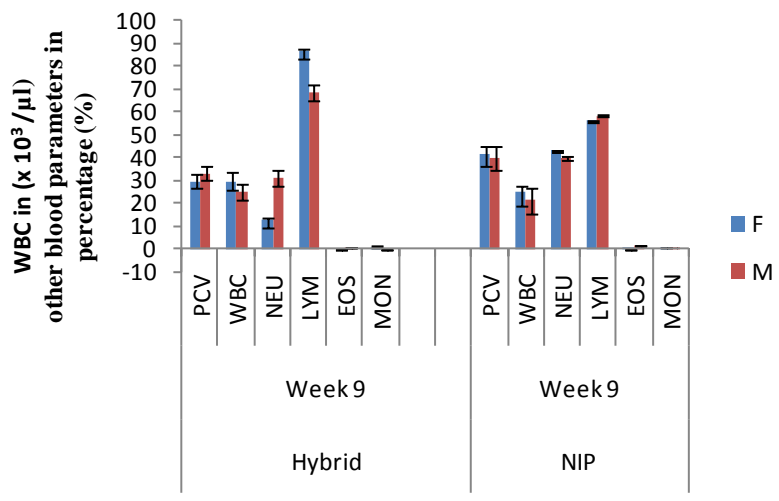

Figure 2. Effect of genotype and sex on white blood cell count at 9 weeks. PCVPacked cell volume, WBC-White blood cell, NEU-Neutrophil, LYM- Lymphocyte, EOS-Eosinophil, MON-Monocytes, M-Male, F-Female, NIPNigerian Indigenous pig.

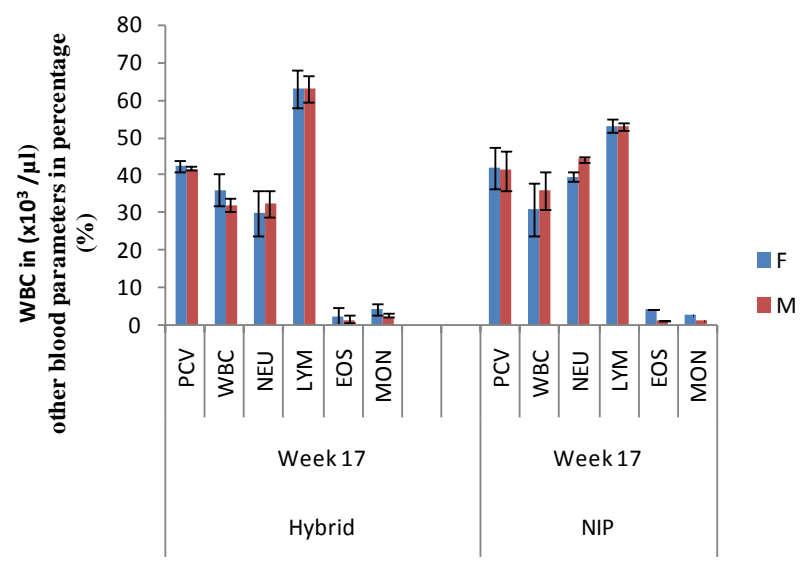

Figure 3. Effect of genotype and sex on white blood cell count at 17 weeks. PCV - Packed cell volume, WBC-White blood cell, NEU-Neutrophil, LYMLymphocyte, EOS—Eosinophil, MON-Monocytes, M-Male, F-Female, NIPNigerian Indigenous Pigs. 


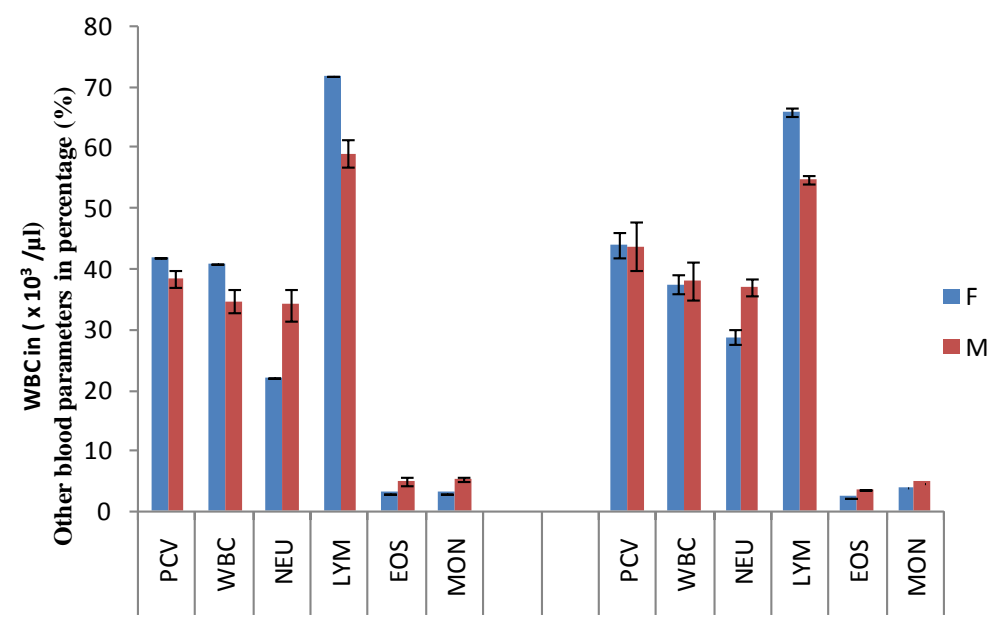

Figure 4. Effect of genotype and sex on white blood cell count at 25 weeks. PCV-Packed cell volume, WBC-White blood cell, NEU-Neutrophil, LYM-Lymphocyte, EOS-Eosinophil, MON—Monocytes, M-Male, F-Female, NIP—Nigerian Indigenous pig.

Table 2. Table type styles (Table caption is indispensable).

\begin{tabular}{|c|c|c|c|}
\hline Age & Traits & Female & Male \\
\hline \multirow[t]{6}{*}{9 weeks } & ${ }^{*} \mathbf{P C V}(\%)$ & $29.00 \pm 4.00^{b}$ & $33.12 \pm 2.73^{\mathrm{a}}$ \\
\hline & "WBC & $28.90 \pm 4.60^{\mathrm{a}}$ & $24.83 \pm 3.15^{\mathrm{b}}$ \\
\hline & ${ }^{*}$ NEU (\%) & $12.50 \pm 1.50^{\mathrm{a}}$ & $31.00 \pm 3.37^{b}$ \\
\hline & ${ }^{*} \mathbf{L Y M}$ (\%) & $87.00 \pm 1.00^{\mathrm{a}}$ & $68.63 \pm 3.43^{b}$ \\
\hline & EOS (\%) & $0.00 \pm 0.00$ & $0.38 \pm 0.18$ \\
\hline & MON (\%) & $0.50 \pm 0.50$ & $0.00 \pm 0.00$ \\
\hline \multicolumn{4}{|l|}{17 weeks } \\
\hline & PCV (\%) & $42.50 \pm 1.50$ & $41.75 \pm 0.45$ \\
\hline & WBC $\left(\times 10^{3} / \mu \mathrm{l}\right)$ & $36.10 \pm 4.20$ & $32.18 \pm 1.92$ \\
\hline & NEU (\%) & $30.00 \pm 6.00$ & $32.38 \pm 3.56$ \\
\hline & LYM (\%) & $63.00 \pm 5.00$ & $63.12 \pm 3.61$ \\
\hline & EOS (\%) & $2.50 \pm 2.50$ & $1.75 \pm 1.03$ \\
\hline & MON (\%) & $4.50 \pm 1.50$ & $2.75 \pm 0.65$ \\
\hline \multicolumn{4}{|l|}{25 weeks } \\
\hline & ${ }^{*}$ PCV (\%) & $42.00 \pm 0.00^{a}$ & $38.33 \pm 1.38^{b}$ \\
\hline & ${ }^{*}$ WBC $\left(\times 10^{3} / \mu \mathrm{l}\right)$ & $41.00 \pm 0.00^{a}$ & $34.63 \pm 1.94^{b}$ \\
\hline & ${ }^{*}$ NEU (\%) & $22.00 \pm 0.00^{b}$ & $34.17 \pm 2.66^{\mathrm{a}}$ \\
\hline & ${ }^{*} \mathbf{L Y M}$ (\%) & $72.00 \pm 0.00^{\mathrm{a}}$ & $59.17 \pm 2.17^{b}$ \\
\hline & ${ }^{*}$ EOS (\%) & $3.00 \pm 0.00^{b}$ & $4.83 \pm 0.65^{\mathrm{a}}$ \\
\hline & "MON (\%) & $3.00 \pm 0.00^{b}$ & $5.17 \pm 0.40^{\mathrm{a}}$ \\
\hline
\end{tabular}

${ }^{\mathrm{a}, \mathrm{b}}$ Mean within the same row with different superscript letters, were different $(\mathrm{P}<0.05)$. ${ }^{*}$ Level of significance $(\mathrm{P}$ $<0.05)$. PCV—Packed cell volume, WBC-White blood cell, NEU—Neutrophil, LYM-Lymphocyte, EOSEosinophil, MON—Monocytes, NIP—Nigerian Indigenous Pig. 
Table 3. Effect of sex and age on Leucocyte traits of Hybrid.

\begin{tabular}{|c|c|c|c|c|}
\hline & Age & Traits & Female & Male \\
\hline & 9 weeks & ${ }^{*}$ PCV (\%) & $41.50 \pm 0.65^{a}$ & $39.75 \pm 1.03^{b}$ \\
\hline & & ${ }^{*}$ WBC $\left(\times 10^{3} / \mu \mathrm{l}\right)$ & $24.55 \pm 1.09^{a}$ & $21.00 \pm 1.50^{b}$ \\
\hline & & ${ }^{*}$ NEU (\%) & $43.00 \pm 3.03^{a}$ & $39.76 \pm 5.59^{b}$ \\
\hline & & ${ }^{*}$ LYM (\%) & $56.00 \pm 3.24^{b}$ & $58.25 \pm 5.30^{\mathrm{a}}$ \\
\hline & & ${ }^{*} \operatorname{EOS}(\%)$ & $0.05 \pm 0.50^{b}$ & $1.50 \pm 0.79^{\mathrm{a}}$ \\
\hline \multirow[t]{5}{*}{ MON (\%) } & $0.50 \pm 0.50$ & $0.50 \pm 0.50$ & & \\
\hline & 17 weeks & & & \\
\hline & & PCV (\%) & $42.00 \pm 1.08$ & $41.25 \pm 2.66$ \\
\hline & & ${ }^{*}$ WBC $\left(\times 10^{3} / \mu \mathrm{l}\right)$ & $30.88 \pm 1.81^{b}$ & $35.90 \pm 2.54^{\mathrm{a}}$ \\
\hline & & ${ }^{*}$ NEU (\%) & $39.50 \pm 5.62^{b}$ & $44.25 \pm 5.27^{\mathrm{a}}$ \\
\hline \multirow[t]{2}{*}{ LYM (\%) } & $53.25 \pm 6.97$ & $53.00 \pm 5.00$ & & \\
\hline & & ${ }^{*} \operatorname{EOS}(\%)$ & $4.25 \pm 1.32^{\mathrm{a}}$ & $1.25 \pm 0.75^{b}$ \\
\hline \multirow[t]{2}{*}{ MON (\%) } & $3.00 \pm 1.73$ & $1.50 \pm 0.96$ & & \\
\hline & 25 weeks & & & \\
\hline \multirow[t]{4}{*}{ PCV (\%) } & $44.00 \pm 0.41$ & $43.75 \pm 1.03$ & & \\
\hline & & WBC $\left(\times 10^{3} / \mu \mathrm{l}\right)$ & $37.43 \pm 2.96$ & $37.98 \pm 1.10$ \\
\hline & & ${ }^{*}$ NEU (\%) & $28.75 \pm 2.14^{b}$ & $37.00 \pm 3.98^{a}$ \\
\hline & & ${ }^{*} \operatorname{LYM}(\%)$ & $66.00 \pm 1.58^{\mathrm{a}}$ & $54.75 \pm 3.18^{b}$ \\
\hline EOS (\%) & $2.30 \pm 1.32$ & \multicolumn{2}{|r|}{$3.50 \pm 1.50$} & \\
\hline MON (\%) & $3.75 \pm 0.75$ & \multicolumn{2}{|r|}{$4.75 \pm 0.75$} & \\
\hline
\end{tabular}

${ }^{\mathrm{a}, \mathrm{b}}$ Mean within the same row with different superscript letters, were different $(\mathrm{P}<0.05)$. ${ }^{*}$ significance $(\mathrm{P}<0.05)$. PCV—Packed cell volume, WBC—White blood cell, NEU—Neutrophil, LYM—Lymphocyte, EOS—Eosinophil, MON—Monocytes.

at 17 and 25 weeks of age with those of the hybrid. The LYM values were higher for Hybrid males and females over the NIP males and females for all ages.

Table 4 and Table 5 show Pearson's correlation coefficient among the leukocyte traits of hybrids and NIPs respectively. There was correlation among the white blood count, the hybrid correlation values were within -0.04 to 0.64 while NIP correlation values were within -0.02 to 0.36 . The highest correlation was found between the PCV and WBC with 0.64 values in hybrid as shown in Table 4 while it was 0.36 between PCV and WBC for NIP as shown in Table 5. In Table 4 and Table 5, the correlation values for hybrid and NIP for WBC and Monocytes $(0.58,0.46)$ and NEU and LYM $(-0.95,-0.93)$ were highly significant $(\mathrm{P}<0.05)$. This positive correlation between WBC and MONO, insinuated that the increase in WBC will cause an increase in MONO while the negative correlation between Neutrophil and Lymphocyte mean that an increase in LYM will cause a decrease in Neutrophil.

\section{Discussion}

The significant variations due to age and breed were observed in this study. This finding was corroborated with Sutherland et al. (2005) [10] and Aladi et al. (2008) [9] where the interaction between pig breed and age were significant during both pre and post weaning age of different breeds of pigs. This variation may be due to genetic control of the individual pigs as described by Renard et al., (1998). The significant effects of age and sex on haematolological parameters, especially, PCV, NEU and LYM, were in collaboration with findings of Radositis et al., 1994 [4] and Egbunike and Ekusu (1983) [7], where sex and age influence haematological values in pigs. According to Egbunike and Ekusu (1983) [7] who reported that the male tend to have higher values than the female. Okeudo et al. (2003) [11] also reported sex-related variation in ducks and guinea fowls. This finding was in contradiction with findings of Aladi et al. (2008) [9] and Eze et al. (2010) [12]. 
Table 4. Pearson correlation coefficients among the white blood count of hybrid.

\begin{tabular}{ccccccc}
\hline & PCV & WBC & NEU & LYM & EOS & MON \\
\hline PCV & 1.00 & 0.64 & 0.52 & -0.60 & 0.18 & 0.41 \\
WBC & & 1.00 & 0.15 & -0.33 & 0.31 & ${ }^{*} \mathbf{0 . 5 8}$ \\
NEU & & 1.00 & ${ }^{*}-\mathbf{0 . 9 5}$ & -0.04 & 0.20 \\
LYM & & & 1.00 & -0.21 & -0.25 \\
EOS & & & & 1.00 & 0.29 \\
MON & & & & & 1.00 \\
\hline
\end{tabular}

${ }^{*}$ Level of significance P $<0.05$. PCV—Packed cell volume, WBC—White blood cell, NEU—Neutrophil, LYMLymphocyte, EOS-Eosinophil, MON-Monocytes.

Table 5. Pearson correlation coefficient among the white blood count of NIP $(\mathrm{P}<0.05)$.

\begin{tabular}{ccccccc} 
& PCV & WBC & NEU & LYM & EOS & MON \\
\hline PCV & 1.00 & ${ }^{*} \mathbf{0 . 3 6}$ & ${ }^{*} \mathbf{0 . 0 2}$ & ${ }^{*}-\mathbf{0 . 0 9}$ & ${ }^{*} \mathbf{0 . 0 2}$ & 0.31 \\
WBC & & 1.00 & -0.18 & 0.03 & 0.25 & ${ }^{*} \mathbf{0 . 4 6}$ \\
NEU & & 1.00 & ${ }^{*}-\mathbf{0 . 9 3}$ & -0.14 & -0.24 \\
LYM & & & 1.00 & -0.15 & ${ }^{*}-\mathbf{0 . 0 6}$ \\
EOS & & & & 1.00 & 0.20 \\
MON & & & & & 1.00 \\
\hline
\end{tabular}

*Level of significance $\mathrm{P}<0.05$. PCV—Packed cell volume, WBC—White blood cell, NEU—Neutrophil, LYMLymphocyte, EOS-Eosinophil, MON-Monocytes.

The NIP had higher value of PCV at 9 and 25 weeks $(40.62 \% \pm 0.65 \%$ and $43.88 \% \pm 1.26 \%)$ respectively than Hybrid value $(32.30 \% \pm 2.45 \%$ and $38.86 \% \pm 1.26 \%)$. This finding is corroborated with Aladi et al. (2008). The NEU and LYM increasing at 17 weeks and then decreasing at 25 weeks of age, was in line with Aladi et al. (2008) [9]. The NIP PCV increased with age. This is contrary to Aladi et al. (2008) [9] findings where the NIP PCV decreases with age.

It was observed from this study that the NIP PCV and the WBC were significantly correlated $(\mathrm{P}<0.05)$ where both increased with age while it was not for hybrid. The negative correlation between NEU and LYM that was significant $(\mathrm{P}<0.05)$ in both breed was observed to be true in hybrid where the NEU increased, LYM decreased with age while in NIP as the NEU increased from 9 weeks to 17 weeks, it then decreased at 25 weeks; while the LYM decreased from 9 weeks to 17 weeks and then increased at 25 weeks.

The WBC that is higher than the normal value for all pigs $\left(7-20 \times 10^{3}\right)$ must be as a result of its contact with pathogen in which the immune system produces more white blood cells to combat the foreign body. This result is in agreement with Eze et al., (2010) [12] where the WBC of the pigs increases above the standard WBC for pigs. White blood cells are important humoral immune cells in blood circulation and they can recognize antigen, kill antigen, clear and circulate immune complexes, they are also involved in immune regulation and have a complete self-regulation system. It is one of the first signs or indicators of disease invasion in animal body. Lunney and Rowland (2011) [13] reported that blood immune traits against diseases could be detected early. This early detection of against diseases through the blood immune traits can be used as criteria for selection at these ages. Leukocyte traits are one of the aspects of innate immune traits which are helpful step towards investigation into any link to disease resistance capacity (immunocompetence) and improve a measure to advance general health in the pig. In order to include immunocompetence in selection for improved health, a major challenge will be to correlate variation in heritable immune traits in healthy animals with inter-individual variability in response to various pathogens. Testing this hypothesis will be a key point for further use of immune traits as indirect selection criteria in multitrait selection to improve resistance to disease. 


\section{References}

[1] Fashina, F.O., Lazarus, D.D., Shamaki, D., Makinde, A.A. and Lombin, L.H. (2010) Field Surveillance and Laboratory Diagnosis of African Swine Fever in Nigeria. First Nigerian International Pig Summit, Institute of Agricultural Research Institute, Ibadan, 22-25 November 2010, 168-170.

[2] Mbanasor, U.U., Anene, B.M., Chime, A.B., Nnaji, T.O., Eze, J.I. and Ezekwe, A.G. (2003) Haematology of Normal and Trypanosome Infected Muturu Cattle in Southeast Nigeria. Nigeria Journal of Animal Production, 30, $236-241$. http://dx.doi.org/10.4314/njap.v30i2.3300

[3] Esonu, B.O., Enenalom, O.O., Udedibie, A.B.I., Herbert, U., Ekpor, C.F., Okoli, I.C. and Iheukwumere, F.C. (2001) Performance and Blood Chemistry of Weaner Pig Fed Raw Mucuna (Velvet Bean) Meal. Tropical Animal Production Investment, 4, 49-55.

[4] Radositis, O.M., Blood, D.C. and Gay, C. (1994) Vetenary Medicine: A Text Book of Diseases of Cattle, Sheep, Sheep, Pigs and Horses. W.B. Sanders Company, London, 25-35.

[5] Adenkola, A.Y., Sackey, A.K.B. and Adelaiye, A.B. (2009) Haematological and Serum Biochemical Changes in Pigs Administered with Ascorbic Acid and Transported by Road for Four Hours during the Harmattan Season. Journal of Cell and Animal Biology, 3, 21-28.

[6] Nasyrova, D.I., Ya. Sapronova, A., Nigmatullina, R.R. and Ugrumov, M.V. (2006) Changes in Blood Plasma Volume in Rats during Ontogenesis. Russia Journal Developmental Biology, 27, 1062-3604. http://dx.doi.org/10.1134/s1062360406050031

[7] Egbunike, G.N. and Akusu, M.O. (1983) Breed and Sex Influences on Porcine Haematological Picture under Hot Humid Climatic Conditions. Veterinary Research Communication, 6, 103-109. http://dx.doi.org/10.1007/BF02214902

[8] Mafuvadze, B. and Erlwanger, K.H. (2007) The Effect of EDTA, Heparin and Storage on the Erythrocyte Osmotic Fragility, Plasma Osmolality and Haematocrit of Adult Ostriches (Struthiocamelus). Veterinary Archives, 77, 427-434.

[9] Aladi, N.O., Okeudo, N.J., Okoli, C.I. and Akanno, E.C. (2008) Reproductive and Haematological Characteristics of the Nigerian Indigenous and Large White pigs in a Humid Tropical Environment. Asian Journal of Animal and Veterinary Advances, 3, 17-23. http://dx.doi.org/10.3923/ajava.2008.17.23

[10] Sutherland, M.A., Rodriguez-Zas, S.L., Ellis, M. and Salak-Johnson, J.L. (2005) Breed and Age Affect Baseline Immune Traits, Cortisol, and Performance in Growing Pigs. Journal of Animal Science, 83, 2087-2095.

[11] Okeudo, N.J., Okoli, I.C. and Igwe, G.O.F. (2003) Heamatological Characteristic of Ducks of Southeastern Nigeria. Tropiculture, 21, 61-65.

[12] Eze, J.I., Onunkwo, J.I., Shoyinka, S.V.O., Chah, F.K., Ngene, A.A., Okolinta, N., Nwanta, J.A. and Onyenwe, I.W. (2010) Haematological Profiles of Pigs Raised Under Intensive Management System in South-Eastern Nigeria. Nigerian Veterinary Journal, 31, 115-123.

[13] Renard, C., Kristensen, B., Gautschi, C., Hruban, V., Fredholm, M. and Vaiman, M. (1988) Joint Report of the First International Comparison Test on Swine Lymphocyte Alloantigens (SLA). Animal Genetics, 19, 63-72. http://dx.doi.org/10.1111/j.1365-2052.1988.tb00792.x 